\title{
Public Behavior as an Output of E-Government Service: The Role of New Technology Integrated in E-Government and Antecedent of Relationship Quality
}

\author{
Taqwa Hariguna ${ }^{1, * \mathbb{D}}$, Athapol Ruangkanjanases ${ }^{2, * \mathbb{C}}$ and Sarmini ${ }^{1}$ \\ 1 Departement of Information System, Universitas Amikom Purwokerto, Purwokerto 53127, Indonesia; \\ sarmini@amikompurwokerto.ac.id \\ 2 Chulalongkorn Business School, Chulalongkorn University, Bangkok 10330, Thailand \\ * Correspondence: taqwa@amikompurwokerto.ac.id (T.H.); athapol@cbs.chula.ac.th (A.R.)
}

\section{check for}

updates

Citation: Hariguna, T.; Ruangkanjanases, A.; Sarmini. Public Behavior as an Output of E-Government Service: The Role of New Technology Integrated in E-Government and Antecedent of Relationship Quality. Sustainability 2021, 13, 7464. https://doi.org/ $10.3390 /$ su13137464

Academic Editors: Manuela Tvaronaviciene and Richard C. Feiock

Received: 17 May 2021

Accepted: 30 June 2021

Published: 4 July 2021

Publisher's Note: MDPI stays neutral with regard to jurisdictional claims in published maps and institutional affiliations.

Copyright: (c) 2021 by the authors. Licensee MDPI, Basel, Switzerland. This article is an open access article distributed under the terms and conditions of the Creative Commons Attribution (CC BY) license (https:// creativecommons.org/licenses/by/ $4.0 /)$.

\begin{abstract}
Electronic government has played an essential role in citizen policy strategy, especially during the COVID-19 pandemic. As part of citizen and government interaction, companies can utilize electronic government facilities to establish direct communication and maintain service quality by integrating new technologies and facilities in electronic government which can provide service via online, embedded with social media integration, implemented with mobile service, using personalized user accounts, e-participation service integration, in combination with ongoing citizen information. Therefore, electronic government facilities must adapt and choose the right content to promote strong citizen relations, leading to citizen behavior to make long-term use of electronic government facilities. This study considered and integrated the latest technology from electronic government and associated it with connection quality. Sustainable motives and faithfulness were used to quantify the quality of citizen relations to electronic government facilities, which can influence the results of citizen behavior. The SmartPLS 2 software was used to quantify and estimate 425 online questionnaire surveys. The results showed that of the 12 hypotheses, eight hypotheses were declared to have a significant effect, consisting of $\mathrm{H1}, \mathrm{H} 2, \mathrm{H} 6-\mathrm{H} 8$, and $\mathrm{H} 10-\mathrm{H} 12$, while the other four hypotheses were stated to have no significant effect, namely H3-H5, and H9. This study was used to guide the government as a provider of electronic government facilities to adapt and provide content following the dimensions of the latest technology to achieve goals and produce sustainable implementation.
\end{abstract}

Keywords: current technology of electronic government; connection quality; citizen behavior; electronic government outcome

\section{Introduction}

The increase in the number of internet users and growth in information technology developments have changed many paradigms of human interaction in conducting business activities, educational activities, and government services. Over recent years, almost all of these activities have shifted to digital forms; in fact, the influence of digital activities in the last five years has often been referred to as the fourth industrial revolution. The current technological developments and the almost evenly distributed use of the internet at all levels of society have accelerated the process of this industrial revolution [1].

The digitalization process has been increasingly felt by all elements, including the government, which has been encouraged to transform its citizen service activities using electronic government. The transformation process is expected to increase citizen transparency, efficiency, and effectiveness in citizen facilities.

Electronic government serves to connect activities between society and the government. People are familiar with the term electronic government and have used other 
government applications to support their activities, such as searching for regional information, tourism potential, e-filing, and electronic citizen cards. The evolution of electronic government is occurring very quickly to facilitate the complex problems faced today and prepare for changes in the future $[1,2]$.

The role of government cannot be separated from service activities to the general citizen. One of the digital channels is electronic government, that can be used as a two-way service media that can adapt to changes both technically, as well as in design and strategy. Electronic government has information content that displays normative aspects and can display two-way interactions directly, therefore, it is helpful to establish a connection between the two. Building content electronic government quality requires a strong effort to provide adaptive innovation to the current conditions to be accepted by the citizen. Therefore, the government, as a service provider, must be able to choose the right content for electronic government quality to increase support to connection quality, which would also affect citizen behavior, and therefore support sustainability of the successful establishment of electronic government service.

Electronic government quality is an important domain that can influence citizens' responses to the quality of facilities provided by the government. Connection quality is a user's concept of what is felt that affects the quality of credence and contentment to the perceived experience.

Previous studies have discussed electronic government quality and connection quality separately. However, there has never been a discussion related to the concept of electronic government quality, connection quality that is integrated into one framework. Additional studies, separately related to the concept of electronic government quality and connection quality, have also been conducted, such as electronic government usage, which is integrated with the theory of expectation confirmation model [3,4]. Wirtz and Kurt [5] described five empirical variables using empirical measures to support citizen use motive [6,7]. While Wirtz and Piehler [6] identified factors that influence success in the implementation of electronic government. In addition, other studies explored connection quality, which is generally used for the field of social network commerce. As explained by [8], connection quality is a mediator between customer behavior with activity commerce in social media and the concept of customer experience. There is a similarity in the substance of customer behavior with citizen behavior on electronic government. Moreover, Chen et al. [9] also integrated connection quality with technology readiness to quantify user concept using e-appointment systems.

This study explores the effect of electronic government quality on citizen/citizen engagement represented by two construct connection qualities. In this study, we also assessed the effect of electronic government quality and connection quality on citizen credence, citizen contentment, citizen faithfulness motive, and citizen participation motive in electronic government activity. We also discuss the definition of each variable or construct in detail, and those constructs are provided in the literature review section. Furthermore, this study concretely provides concepts and guidance to the government for building electronic government facilities as a medium for citizen interaction that can access all facilities provided by the government, and therefore the implementation of electronic government can affect citizen value. Hariguna et al. [3] reported that information system quality used in electronic government facilities can stimulate the implementation of citizen value. Therefore, this study sets out a framework that integrates electronic government quality with connection quality to overcome the gap.

\section{Literature Review}

\subsection{Concept and Theory of Electronic Government}

The implementation of electronic government has shifted to e-facilities, and it is user oriented [10]. However, today's scientific discourse still often ignores these shifts, where many studies today focus more on the application of electronic commerce and the use of user-oriented technology in general. More specifically, existing studies often adapt 
based on literature reviews and web-technology implementation, or commerce approaches related to the context of electronic government, and therefore they use generic abstract designs $[11,12]$. For example, the technology approval model (TAM) concept is most often used in measuring user approval with the utility and ease of use variables. However, for assessing citizen approval of electronic government, both constructs are not relevant enough and still require other variable constructs. In addition, several previous studies have confirmed that the variable, ease of use, has a positive and significant effect on the variable of perceived utility, which also affects the general motive of electronic government. Some studies that adopted the framework Delone and McLean called (D\&M IS Success Model) have mentioned that the system's quality, information quality, and service quality variables affect the variable of citizens' motive to use electronic government. However, antithesis to some traditional studies of IS, the variable of system's quality shows a weak correlation with the variable of intended use [13-15]. While based on the concept of innovation diffusion theory (IDT), it is predicted that the compatibility of independent variables, most excellence, complexity, and imagery all correlate with the variable of motives dependently. Therefore, considering multi-theory studies that combine two or more of the theories listed above, in this study, we were more likely to analyze the design of credence in the electronic government and construct credence in the paradigm of internet studies. Moreover, the results explained that variable of credence has a positive influence in describing the application of electronic government.

Studies using constructs into citizen motive of electronic government, confirmed by some scholars, are still in their early phases and growing; however, they provide some important points of view and concepts for citizens and government sectors. Notwithstanding the fundamental restructuring of citizen administration in the rapid development of information technology and the changing tendency of users of online media, previous studies have analyzed factors that establish that citizen motive usage of electronic government is still not appropriate. One of the reasons is the suitability of information systems and e-commerce models in general that are only technology-oriented $[16,17]$. This is not following the electronic government domain, because the elements in electronic government are very different from the context of IS study, social media commerce, or electronic commerce study. In addition, the implementation of the variable IS and the variable of e-commerce for the electronic government context is not strong enough to consider specific differences in electronic government systems, facilities, and users. The constructs of IDT theory that are often used, variable usability and variable ease of use, are also not suitable for assessing the motive of using electronic government. The same goes for meta-emotional designs that focus on a user's emotional status, such as credence on the internet, perceived credibility, social influence, concept of risk, and subjective rules. This design precludes the identification of appropriate management parameters for well-planned user-oriented electronic government.

With this observation, in this study, we describe designs that are separated from the perspective of technology approval based on the IDT concept. This design explicitly considers citizen facilities electronically that reflect the needs of the citizens and meet the requirements of modern electronic government technology.

\subsection{Concept and Theory of Relationship Quality}

Relationship quality (RQ) represents the collaborative motive, connection, and feedback activity between two parties, as well as the intense communication between the two parties [18,19]. Tajvidi et al. [20] explained that in communicating we must focus on the connection between two parties, namely service providers and service users. Anastasiei et al. [21] mentioned credence as part of the connection quality dimension that depends on the type of message conveyed by the provider. Connection quality is an important factor for developing a positive connection [22], maintaining user faithfulness [23], encouraging purchase or reuse motive [24,25], and motiving continuous engagement in social activities [26]. 
$\mathrm{RQ}$ is considered to be a composite or multidimensional building because it basically consists of three different components related to credence, contentment, and responsibility $[19,27]$. However, this study only focuses on credence and contentment, in this case, credence and contentment in the design of connection quality: First, many previous studies have discussed RQ as a secondary form variable of credence and contentment as a measurement $[9,28-30]$, if responsibility is removed, then, in design it did not show a significant difference. Second, responsibility is sourced from the results of connection quality [31] which is owned by user faithfulness [32], and in addition, some literature state that actually responsibility is not part of the design of connection quality [33-35].

Previous studies have stated that the citizen contentment variable has an important influence on citizens' motives when they use electronic government [3]. Furthermore, the variable of citizen credence also gives a positive value to the motive of citizens to use electronic government [36]. These two variables are the constructor extraction of connection quality. Furthermore, Khan et al. [37] explained that there are two antecedent variables of social media for electronic government facilities, namely credence and contentment.

Most studies regard RQ as mediating between predecessors and consequences. A study found that the RQ between users and social networking sites can mediate the impact of social engagement and quality value from the website on motive to use. Masri et al. [38] also explained that one's motive adds value to customer contentment. There is a good connection with contentment, credence, and sustainable motive which are all due to the quality of the information system. Perceived value affects contentment and credence. Tsai and Huang [39] also mentioned faithfulness. The existence of faithfulness is due to the RQ which is influenced by self-conformity, social rules, information based on quality aspect, and interactivity.

\subsection{Public Behavioral Output}

In the concept of electronic government, there is a commerce concept which states that connections based on building and maintaining RQ with customers can certainly have positive consequences. This can be seen in faithfulness, word-of-mouth (WoM), and implementation. Meyer [40] and Aymagambetov et al. [41] ensured the importance of using sustainable electronic government and maintaining the RQ. People routinely use electronic government facilities, and this can continue because to get attention, people need more time and effort. In addition, service providers or media are the key to success that can provide feedback on these facilities.

Take for example the application of citizen behavior such as motive and faithfulness. Reuse motive is the society's desire to reuse a service. Schiffman and Kanuk [42] argued that motive is the likelihood that a person will reuse a particular service, with more substantial considerations than they previously perceived. People use electronic government facilities to seek relevant knowledge that is influenced by their concepts and the surrounding surroundings. After obtaining the knowledge needed, society, then, analyzes, examines, compares, and ends it, based on a prior study showing that motive is the main criterion of people's behavior [43-45].

The psychological aspect felt by citizens after using electronic government can be seen from the concept of faithfulness. The higher the perceived positive aspects of electronic government facilities, the more the value of citizen faithfulness to electronic government increases [46]. In the perspective of mobile government facilities, citizen motive to use is an inseparable part of the citizen perceived value variable and is also a determining factor for the sustainability of mobile government [47]. Meanwhile, according to Alarabiat et al. [48], citizen motive is a moderating variable for citizens who engage in government social media.

Faithfulness is the long-term ability of society to reuse the facilities provided. Faithfulness provides long-term merits to service providers and can also provide assurance [49-51]. For this reason, citizen responsibility is needed to maintain good relations with service providers [52]. From the commerce side, the motive of citizen participation needs to be considered if you want to achieve good information distribution [53]. The participation 
motive is society's desire to engage in activities carried out by the government [54], which, in turn, provide advice and service recommendations [26]. This study uses motive and faithfulness as citizen behavior that reflects the utilization of the combination of electronic government quality with connection quality. Dealing with the construct definition as we explained earlier, here is further explanation about it as it is shown in Table 1 below:

Table 1. Construct definitions.

\begin{tabular}{|c|c|c|}
\hline Construct & Definition & Source \\
\hline Relationship Quality (RQ) & $\begin{array}{l}\text { The level of the whole valuation of the } \\
\text { force of a connection between electronic } \\
\text { government quality domains to the citizen } \\
\text { as the electronic government users. }\end{array}$ & $\begin{array}{l}\text { Crosby et al. [18], } \\
\text { Palmatier et al. [19], and Tajvidi et al. [20] }\end{array}$ \\
\hline Public Intention (PPI) & $\begin{array}{l}\text { Citizen compliance to use an electronic } \\
\text { government after perceiving connection } \\
\text { quality and electronic government quality. }\end{array}$ & $\begin{array}{l}\text { Dodds et al. [55] and } \\
\text { Bonsón Ponte et al. [56] }\end{array}$ \\
\hline Public Loyalty (PL) & $\begin{array}{l}\text { Citizen compliance to be a faithful and } \\
\text { committed citizen after perceiving electronic } \\
\text { government quality and connection quality. }\end{array}$ & $\begin{array}{l}\text { Flavián et al. [49] and } \\
\text { Zhang et al. [57] }\end{array}$ \\
\hline Full Online Service (FOS) & $\begin{array}{l}\text { Citizen concept-related electronic government } \\
\text { strategy of modern and their concept when } \\
\text { electronic government full online facilities. }\end{array}$ & Assar et al. [58] \\
\hline Social Media Integration (SMI) & $\begin{array}{l}\text { Measuring the citizen social networking } \\
\text { activities and understanding their concept } \\
\text { towards electronic government service. }\end{array}$ & Bonsón et al. [59] \\
\hline Mobile Service Combination (MSI) & $\begin{array}{l}\text { Measuring citizen concept toward } \\
\text { integrated mobile government service } \\
\text { and their understanding. }\end{array}$ & Al-Hujran [60], Zamzami and Mahmud [61] \\
\hline Personalized User Account (PUA) & $\begin{array}{l}\text { Measuring and understanding citizen } \\
\text { concept related to a personalized user } \\
\text { account in electronic government service. }\end{array}$ & $\begin{array}{l}\text { Thongpapanl and Rehman Ashraf [62], } \\
\text { Liao et al. [63] }\end{array}$ \\
\hline $\begin{array}{l}\text { Electronic Participation Service Integration } \\
\qquad(\text { PSI) }\end{array}$ & $\begin{array}{l}\text { Measuring citizen opinion of } \\
\text { e-participation service combination } \\
\text { in electronic government service. }\end{array}$ & Zheng et al. [64] and Themistocleous et al. [65] \\
\hline Currentness of Public Information (CPI) & $\begin{array}{l}\text { Understanding citizen awareness } \\
\text { of the current situation. }\end{array}$ & $\begin{array}{l}\text { Lee and Kozar [66], Smith [67], } \\
\text { Dragulanescu [68], and Lakeworth [69] }\end{array}$ \\
\hline
\end{tabular}

\section{Hypotheses Development}

The growing digital media encourages policy makers, in this case the government, to transform and interact with the citizens through digital media, especially social media, to interact with each other and develop connections so that they can generate profits. In electronic government, the profit earned for the government is caused by citizen behavior, including the citizens' motives and faithfulness in using electronic government. As part of the connection quality dimension, people's motives are influenced by several things, including credence and contentment. Positive credence $[25,56,70]$ can play an important role in increasing citizen motives. Meanwhile, contentment as one of the constructs of connection quality [54] significantly influences citizen motives [24,71,72]. Apart from motive, citizen faithfulness has been a significant outcome representing a good connection between government and citizen $[57,73]$. Through virtual channels, citizen interaction will affect ongoing citizen faithfulness.

On the basis of the discussion above, this study concludes that the positive connection between society and the government can increase if society implements and utilizes electronic government facilities. Once again, all this is interwoven through electronic government facilities. In other words, this situation can increase citizens' motive due to the excellent connection with the facilities they receive. In addition, good relations between the citizen and electronic government facilities can create citizen faithfulness and citizen desire to actively engage with electronic government facilities. Therefore, this study set outs $\mathrm{H} 1-\mathrm{H} 2$ as follows. 
Hypothesis 1 (H1): RQ has a positive and significant effect on PPI.

Hypothesis 2 (H2): RQ has a positive and significant effect on PL.

Full online service (FOS) is one criterion for measuring citizen facilities. To be able to interact fully online, society does not have to meet face-to-face with the local government, where all citizen facilities can be run through electronic government. In this situation, electronic government can be used as the only media link between society and the government. However, of course, this depends on the level of maturity of society in an area [74]. In addition, FOS facilities provide a concrete picture of electronic government facilities because people can use electronic government facilities without time and place restrictions. This condition has a significant influence on the RQ (citizen credence and citizen contentment) between the citizen and the government.

Because this method provides many merits for the citizen and also for the government, the implementation of FOS must be managed and utilized massively [74,75], such as considering the low cost and shorter time. Al-Sebie [75] explained that there are still few studies that have developed and integrated transactional, or developed and integrative facilities involving FOSs. Existing studies do not empirically examine the effect of using FOS on general motive and RQ in electronic government [58]. However, they are more likely to only set out a conceptual framework on this topic and only limited to understanding the maturity of electronic government. Therefore, this study shows that FOS has an influence on citizen motive to use electronic government and RQ. Thus, we formulate the following hypothesis:

Hypothesis 3 (H3): Technology FOS has a positive and significant effect on PPI.

Hypothesis 4 (H4): Technology FOS has a positive and significant effect on the citizen RQ.

Mobile service integration (MSI) and smartphone social media have also become tools in public daily lives everywhere. Several profit agencies and governments have designed and implemented smartphone-linked website facilities. Both practitioners and researchers have realized several merits of mobile government for citizens who use citizen facilities, including being a real-time source of information, location based on demand, making transactional electronic facilities, and reaching the citizen anywhere online. It is mobile-based and also provides innovative special facilities.

The implementation of mobile government is still in its very early stages [60] but the advantages offered by some of the more advanced electronic governments are expanding the provision of mobile facilities on their websites gradually. The current study shows that electronic government related information and facilities such as $\mathrm{m}$-health and medical facilities, $\mathrm{m}$-filling, and $\mathrm{m}$-culture are now provided in various countries on official mobile applications. Since the transition from electronic government to mobile government, research on the combination of mobile government is needed because the combination of mobile government facilities has not yet been achieved [76]. Furthermore, other problems related to the quality and approval of the use of $\mathrm{m}$-facilities have also arisen in society [61] The switch to mobile government has not been thoroughly discussed [77], therefore, this study set outs that integrating mobile service into electronic government can influence usage motives, leading us to the following hypothesis:

Hypothesis 5 (H5): MSI in electronic government has a positive and significant effect on the $R Q$ of citizen.

Hypothesis 6 (H6): MSI in electronic government has a positive and significant effect on PPI.

In relation to social media integration (SMI), according to [5], in recent years, many companies have used social media in their corporate activities, especially to increase productivity and distribution of information. Companies as well as citizen administrations 
also benefit from the use of social media because it provides a strong platform. Social media also helps the government communicate directly with constituents. In addition, websites can provide various information links that we need by integrating various social media links across digital platforms such as Twitter, Instagram, Facebook, YouTube, etc.

Today, the fundamental combination of social media into electronic government can change the process of citizen authority $[78,79]$. Promoting citizen involvement in administrative processes creates a higher level of transparency and the connection between citizens and government can be significantly improved. Simultaneously, citizens' interest is growing due to the changing habits of online users $[56,80]$. Thus, enabling the design of a system in the provision of electronic government facilities through social media applications. Therefore, social media integrated into electronic government can be an important factor in determining the $\mathrm{RQ}$, and this can strengthen citizens' motive to use electronic government facilities. Therefore, this research set outs the following hypothesis:

Hypothesis 7 (H7): SMI into electronic government has a positive and significant effect on citizen $R Q$ in using electronic government.

Regarding personalized user accounts (PUA), the trend of electronic government has been towards a high level of personalization or customization of facilities at the individual level, where, through preferred channels, citizens can choose the facilities that they want. Citizens can design a different service portfolio or dashboard. Therefore, officers can implement their own personalized electronic government facilities. Citizens can create personalized user accounts through their mobile accounts. For example, online service arrangements can be made such as creating checklists to facilitate access, subscriptions, reminders, and notifications from the government to individuals using various media or viewing government billing accounts, and making online payments.

The role of personalized electronic government facilities needs to be investigated. Regarding e-commerce research, personalization of web content can be tested using PUA concepts, including attribute such as catalog navigation and product view customization. With this personalization system, it can produce good quality online implementation and increase customer contentment, faithfulness, and sales [62,63]. However, there are some things to consider such as user privacy issues in website management and personalized facilities $[81,82]$. Furthermore, in several empirical studies related to personalization in electronic commerce, the role of personalization in the field of electronic government has not been sufficiently assessed. Furthermore, regarding personalization in e-commerce, studies have ignored the role of personalization in electronic government.

Studies on the personalization of electronic government facilities have yielded several findings, including personalization of electronic government facilities in the citizen section can positively improve the $R Q$, which in turn affects the use of personalized electronic government content.

Furthermore, studies have also suggested that electronic government provides solutions to problems related to access, credence, control, and privacy in electronic government personalization. These findings suggest that studies on personalized electronic government ae needed. Therefore, the effect of personalization on citizens' motive to use web portals can be used as a criterion to assess the effectiveness of personalized electronic government content.

According to these observations, personalized web content and facilities for electronic government in offering personalized and individualized user accounts are crucial elements in determining the quality of citizen relations. The hypothesis put forward in this study is:

Hypothesis 8 (H8): PUA in electronic government has a positive and significant effect on the citizen $R Q$ to use electronic government.

Regarding e-participation service integration (PSI), it can be said that one of the media that has complete access effectiveness between the government and citizens in providing more inclusive facilities is electronic government [83]. This happens because of citizen 
involvement in the policy process [84] and citizen participation to collaborate with other citizens to promote democratic values $[85,86]$ regarding electronic government projects that are continuously being developed, technology expansion, involvement, and citizen participation called e-participation [64]. Some cities have built e-participation facilities in their electronic government gradually. In addition, based on the conclusions of benchmarking in this study, this website is considered to be at a different stage of maturity regarding the implementation of e-participation facilities. However, in general, electronic government tends to promote citizen e-participation because it provides many facilities. Most researchers agree that there is a significant gap in the literature on the connection between service management e-participation and citizen experiences of e-participation [86,87]. Therefore, knowledge of the effect of e-service combination participation in electronic government on the quality of citizen relations and motives can help fill this gap, therefore, this study presents the following hypothesis:

Hypothesis 9 (H9): PSI into electronic government has a positive and significant effect on the citizen $R Q$.

Hypothesis 10 (H10): PSI into electronic government has a positive and significant effect on PPI.

IS quality has been investigated in previous studies. The concept of current public information (CPI), King and Epstein [88] stated that the condition for information to be valuable is if it has high accuracy. Therefore, the current factor as a substantial element of website quality needs to be considered when creating the information component of a website $[66,67]$. In this context, Dragulanescu [68] included the variable current as one of the criteria for evaluating websites and determining the extent to which information was distributed. Lakeworth [69] also extended and defined contemporary as the accuracy of information that can be enhanced by the truth and relevancy of current information.

Currently electronic government provides various government information, data, statistics, and provides other citizen electronic facilities. Updating information and citizen facilities is an integral part of the standard guidelines for designing websites for government agencies. If electronic government is designed and maintained properly, and always provides contemporary information and facilities, the maximum accuracy value is obtained. Updating information and citizen facilities is a determinant of the high quality of electronic government, therefore, this study set outs the following hypotheses:

Hypothesis 11 (H11): CPI in electronic government has a positive and significant effect on PPI to use electronic government.

Hypothesis 12 (H12): CPI in electronic government has a positive and significant effect on the citizen $R Q$ in the use of electronic government.

\section{Research Method}

The purpose of this study is to quantify the six variables of the quality of the antecedent connection and quantify the effect of these connections, resulting in the outcome of citizen behavior in the context of Electronic Government, so that the methodology in data collection becomes very important to note. In this study, the steps taken consisted of distributing questionnaires, collecting data, filtering data, analyzing data to get concrete conclusions.

The method used for data sample collection was by distributing online questionnaires; the questionnaire was created using Google Forms; the interaction media which was used to send questionnaires were using email and social media (Whatsapp, Telegram, Twitter and Facebook). The distribution of data sampling started from January 2021 to April 2021. Participants in this study were citizen Electronic Government users in Indonesia who have used e-facilities -government in interactive activities with the government.

Data filtering was carried out to classify Electronic Government users who do not have experience. Of the 512 respondents who filled out the questionnaire, only 425 were quali- 
fied and had experience with Electronic Government. Table 2 presents the demographic composition of repeat respondents.

Table 2. Demographics sample.

\begin{tabular}{|c|c|c|c|}
\hline Characteristic & Items & Frequency & Percentage \\
\hline \multirow{2}{*}{ Gender } & Male & 225 & $53 \%$ \\
\hline & Female & 200 & $47 \%$ \\
\hline \multirow{3}{*}{ Education Level } & High School & 100 & $24 \%$ \\
\hline & Undergraduate & 186 & $44 \%$ \\
\hline & Post Graduate & 139 & $33 \%$ \\
\hline \multirow{3}{*}{ Experience using Electronic Government } & Less than 1 year & 71 & $17 \%$ \\
\hline & $2-3$ years & 226 & $53 \%$ \\
\hline & More than 3 years & 128 & $30 \%$ \\
\hline \multirow{4}{*}{ Age } & Less than 25 years old & 75 & $18 \%$ \\
\hline & $26-30$ years old & 105 & $25 \%$ \\
\hline & 31-35 years old & 132 & $31 \%$ \\
\hline & More than 36 years & 113 & $27 \%$ \\
\hline
\end{tabular}

The questionnaire was separated into 2 parts, namely questions about demographic data and hypothetical quantifies. As described in Figure 1, this research developed an overall model based on the framework used in prior studies. Questions were based on a preliminary research and pre-validation scale. The reasonableness of the contents of the questionnaire was then examined correctly. A seven-point Likert scale was usage in this research to improve the rigor of the scale [89].

In the outline part of the questionnaire, each respondent was required to provide an email to prevent them from taking the survey multiple times.

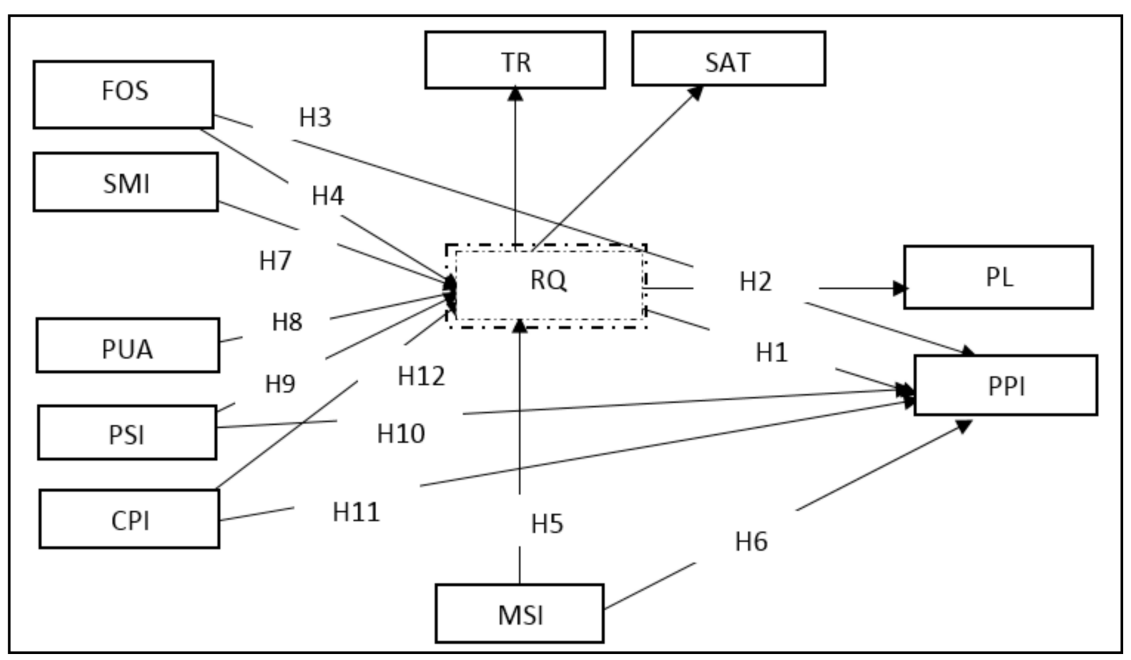

Figure 1. Research framework and hypotheses.

\section{Data Analysis}

Quantify and data analysis of PLS was carried out using SmartPLS 2 software. Table 3 describes the quantify items used in this study. At this stage, the analysis quantifies dependability and reasonableness by testing the structure of the model created. Both stages aim to confirm the dependability and reasonableness of the constructs to ensure the interaction between constructs and construct items is valid and reliable [90]. This study 
explores the causal interactions among FOS, MSI, PUA, PSI, CPI, SMI, RQ, PL, and PPI practices, each containing various quantify items discussed in previous studies.

Table 3. Quantify items on the questionnaire.

\begin{tabular}{|c|c|}
\hline \multicolumn{2}{|c|}{ Quantify Items } \\
\hline \multicolumn{2}{|c|}{ Relationship Quality, source $[25,56,70]$} \\
\hline SAT1 & How satisfied are you with electronic government service? \\
\hline SAT2 & I felt happy with the experience during using of the electronic government \\
\hline SAT3 & Overall, I felt satisfied using the electronic government \\
\hline TR1 & Electronic government service is credence worthy \\
\hline TR2 & I have full confidence in the electronic government service \\
\hline TR3 & If I required help, the provider would do his/her best service to help me. \\
\hline \multicolumn{2}{|c|}{ Public Perceived Intention, source $[24,71,72]$} \\
\hline PPI1 & I am likely to use electronic government service \\
\hline PPI2 & I would consider using electronic government service in the future \\
\hline PPI3 & It is possible that I will use electronic government service in the near future. \\
\hline \multicolumn{2}{|c|}{ Public Faithfulness or loyalty, source $[57,73]$} \\
\hline PL1 & I will use another electronic government service offered by the government in the future \\
\hline PL2 & I will suggest or encourage to colleagues and society to use electronic government service \\
\hline PL3 & I intend to recommend using electronic government service to others \\
\hline \multicolumn{2}{|c|}{ Full Online Service, source [58] } \\
\hline FOS1 & The full online service encourages me to use electronic government service. \\
\hline FOS2 & Full online service in electronic government makes me feel comfortable \\
\hline FOS3 & The full online service in electronic government are very helpful for me \\
\hline \multicolumn{2}{|c|}{ Social Media Integration, source $[56,80]$} \\
\hline SMI1 & Social media combination is helpful in order to encourage me to use electronic Government \\
\hline SMI2 & I intend to recommend use electronic government service to others through social media \\
\hline SMI3 & Using social media, easily for me to get information, electronic government link directly \\
\hline \multicolumn{2}{|c|}{ Mobile Service Integration, source $[60,61]$} \\
\hline MSI1 & Mobile service combination makes electronic government easier to use \\
\hline MSI2 & Mobile government is suitable for my current needs \\
\hline MSI3 & I support the government to expand mobile service \\
\hline \multicolumn{2}{|c|}{ Personalized User Account, source $[62,63]$} \\
\hline PUA1 & Currently, I need a personalized user account for electronic government facilities \\
\hline PUA2 & Having personalized user accounts in electronic government facilities helps me increase my productivity \\
\hline PUA3 & Personalized user account in electronic government service makes me more comfortable in interacting \\
\hline \multicolumn{2}{|c|}{ Electronic Participation Service Integration, source $[64,65]$} \\
\hline PSI1 & Combination of electronic participation facilities in electronic government makes me feel free to give opinions to the government \\
\hline PSI2 & E-participation service is beneficial for me \\
\hline PSI3 & Using e-participation service, I can interact with the government easily \\
\hline \multicolumn{2}{|c|}{ Currentness of Public Information, Source [66-69] } \\
\hline CPI1 & I need information up to date and an official from the government \\
\hline CPI2 & The ongoing of citizen information make me feel satisfied using electronic government \\
\hline CPI3 & I will credence electronic government service if they can give me ongoing of citizen information \\
\hline
\end{tabular}

PLS is more appropriate for this study than the SEM analysis (structural equation model) approach for the following reasons: First, the concept of PLS is very appropriate to explain causal connections between variables and can handle the model built and the items quantify simultaneously [91]. In addition, PLS can estimate complex predictive models, and can also measure multiple research constructs or variables [92]. This study model looks at several preliminary pathways and connection quality connections and two behavioral outcomes that are considered complex models.

Furthermore, the process of reflective and formative criterions can be assessed simultaneously by PLS, it can be concluded that PLS is superior to covariance-based SEM [92,93], and the other methods only solve or measure reflective criterions. 
However, there are weaknesses in the PLS method [94]. First, PLS-SEM uses the model parameters, and then assesses the path of the structural model in the second step. Therefore, to confirm that the quantify items are appropriate for the study, the questionnaire needs to be verified first, in order to produce correct findings.

Another problem that limits the use of PLS-SEM for examination and confirmation is the absence of a global quantify of model fit. Therefore, this study adopted the goodness of fit obtained from manual calculations based on previous studies that have been proven.

\subsection{Outer Model Validation}

Dependability analysis, convergence reasonableness, and discriminant reasonableness are three fundamental aspects that are tested in the validation of the outer model. For composite dependability values or criteria, in order for design dependability to be accepted, all designs must have a value above 0.7. According to the suggestion by [95], if the loading factor is more than 0.5 and the AVE is more than 0.5 , then, the construct reasonableness is convergent. The results of the loading factor and dependability tests are presented in Table 4. Furthermore, the degree of difference between the quantified criteria and the various constructs is expressed in discriminant reasonableness.

Table 4. Analysis of dependability and reasonableness of convergent.

\begin{tabular}{|c|c|c|c|c|}
\hline Quantify Item & Factor Loading & AVE & Composite Dependability & Cronbach's Alpha \\
\hline \multirow{4}{*}{ CPI } & CPI1 $=0.918$ & & & \\
\hline & $\mathrm{CPI} 2=0.954$ & 0.8843 & 0.9582 & 0.9347 \\
\hline & $\mathrm{CPI} 3=0.949$ & & & \\
\hline & $\mathrm{FOS} 1=0.904$ & & & \\
\hline \multirow[t]{3}{*}{ FOS } & $\mathrm{FOS} 2=0.879$ & 0.7817 & 0.9148 & 0.8604 \\
\hline & FOS3 $=0.869$ & & & \\
\hline & MSI1 $=0.911$ & & & \\
\hline \multirow[t]{3}{*}{ MSI } & MSI2 $=0.904$ & 0.8105 & 0.9277 & 0.8832 \\
\hline & $\mathrm{MSI} 3=0.886$ & & & \\
\hline & PL1 $=0.904$ & & & \\
\hline \multirow[t]{3}{*}{ PL } & PL2 $=0.904$ & 0.8137 & 0.9291 & 0.8867 \\
\hline & PL3 $=0.899$ & & & \\
\hline & PPI1 $=0.893$ & & & \\
\hline \multirow[t]{3}{*}{ PPI } & PPI2 $=0.856$ & 0.772 & 0.9103 & 0.8521 \\
\hline & $\mathrm{PPI} 3=0.887$ & & & \\
\hline & PSI1 $=0.793$ & & & \\
\hline \multirow[t]{3}{*}{ PSI } & PSI2 $=0.930$ & 0.7748 & 0.9113 & 0.8545 \\
\hline & PSI3 $=0.912$ & & & \\
\hline & PUA1 $=0.919$ & & & \\
\hline \multirow[t]{3}{*}{ PUA } & PUA2 $=0.934$ & 0.7914 & 0.9189 & 0.8682 \\
\hline & PUA3 $=0.811$ & & & \\
\hline & SAT1 $=0.902$ & & & \\
\hline \multirow[t]{3}{*}{ SAT } & SAT2 $=0.859$ & 0.7952 & 0.9209 & 0.871 \\
\hline & SAT3 $=0.913$ & & & \\
\hline & SMI1 = 0.925 & & & \\
\hline \multirow[t]{3}{*}{ SMI } & SMI2 $=0.815$ & 0.7873 & 0.9171 & 0.8663 \\
\hline & SMI3 $=0.918$ & & & \\
\hline & $\mathrm{TR} 1=0.841$ & & & \\
\hline \multirow[t]{2}{*}{ TR } & $\mathrm{TR} 2=0.919$ & 0.784 & 0.9158 & 0.862 \\
\hline & $\mathrm{TR} 3=0.895$ & & & \\
\hline
\end{tabular}

Each variable is considered to have met the reasonableness of discrimination if the loading factor of each latent item in each construct is higher than the loading factor in each of the other constructs [96] or if the square root of AVE is greater than the correlation of the constructs [95], as described in Table 5 cross-loading and Table 6 correlation matrix, both show strong discriminant reasonableness. 
Table 5. Factor loadings and cross-loadings.

\begin{tabular}{|c|c|c|c|c|c|c|c|c|c|c|}
\hline & CPI & FOS & MSI & PL & PPI & PSI & PUA & SAT & SMI & TR \\
\hline CPI1 & 0.918 & 0.549 & 0.555 & 0.766 & 0.758 & 0.799 & 0.589 & 0.518 & 0.503 & 0.682 \\
\hline CPI2 & 0.954 & 0.649 & 0.649 & 0.850 & 0.842 & 0.810 & 0.690 & 0.634 & 0.569 & 0.766 \\
\hline CPI3 & 0.949 & 0.676 & 0.679 & 0.899 & 0.896 & 0.818 & 0.696 & 0.642 & 0.597 & 0.828 \\
\hline FOS1 & 0.638 & 0.904 & 0.901 & 0.769 & 0.753 & 0.667 & 0.812 & 0.795 & 0.804 & 0.803 \\
\hline FOS2 & 0.614 & 0.879 & 0.862 & 0.767 & 0.748 & 0.649 & 0.821 & 0.858 & 0.667 & 0.785 \\
\hline FOS3 & 0.514 & 0.869 & 0.859 & 0.672 & 0.635 & 0.534 & 0.745 & 0.840 & 0.701 & 0.735 \\
\hline MSI1 & 0.646 & 0.904 & 0.911 & 0.779 & 0.765 & 0.675 & 0.821 & 0.801 & 0.812 & 0.811 \\
\hline MSI2 & 0.626 & 0.891 & 0.904 & 0.796 & 0.778 & 0.664 & 0.855 & 0.907 & 0.707 & 0.821 \\
\hline MSI3 & 0.536 & 0.875 & 0.886 & 0.701 & 0.659 & 0.565 & 0.775 & 0.869 & 0.720 & 0.766 \\
\hline PL1 & 0.807 & 0.686 & 0.695 & 0.904 & 0.905 & 0.930 & 0.732 & 0.682 & 0.665 & 0.760 \\
\hline PL2 & 0.695 & 0.866 & 0.881 & 0.904 & 0.862 & 0.695 & 0.919 & 0.932 & 0.723 & 0.930 \\
\hline PL3 & 0.949 & 0.676 & 0.679 & 0.899 & 0.896 & 0.818 & 0.696 & 0.642 & 0.597 & 0.828 \\
\hline PPI1 & 0.771 & 0.657 & 0.662 & 0.860 & 0.893 & 0.890 & 0.693 & 0.654 & 0.639 & 0.719 \\
\hline PPI2 & 0.668 & 0.833 & 0.850 & 0.869 & 0.856 & 0.681 & 0.880 & 0.882 & 0.711 & 0.882 \\
\hline PPI3 & 0.899 & 0.642 & 0.646 & 0.858 & 0.887 & 0.781 & 0.668 & 0.616 & 0.560 & 0.788 \\
\hline PSI1 & 0.616 & 0.471 & 0.474 & 0.601 & 0.610 & 0.793 & 0.585 & 0.448 & 0.594 & 0.539 \\
\hline PSI2 & 0.807 & 0.686 & 0.695 & 0.904 & 0.905 & 0.930 & 0.732 & 0.682 & 0.665 & 0.760 \\
\hline PSI3 & 0.825 & 0.662 & 0.667 & 0.809 & 0.805 & 0.912 & 0.689 & 0.626 & 0.581 & 0.732 \\
\hline PUA1 & 0.695 & 0.866 & 0.881 & 0.904 & 0.862 & 0.695 & 0.919 & 0.932 & 0.723 & 0.930 \\
\hline PUA2 & 0.619 & 0.823 & 0.833 & 0.765 & 0.731 & 0.665 & 0.934 & 0.820 & 0.752 & 0.897 \\
\hline PUA3 & 0.550 & 0.690 & 0.693 & 0.651 & 0.652 & 0.695 & 0.811 & 0.638 & 0.762 & 0.662 \\
\hline SAT1 & 0.605 & 0.870 & 0.879 & 0.779 & 0.770 & 0.656 & 0.842 & 0.902 & 0.699 & 0.805 \\
\hline SAT2 & 0.501 & 0.852 & 0.862 & 0.670 & 0.625 & 0.534 & 0.755 & 0.859 & 0.704 & 0.738 \\
\hline SAT3 & 0.602 & 0.795 & 0.815 & 0.819 & 0.779 & 0.617 & 0.834 & 0.913 & 0.649 & 0.845 \\
\hline SMI1 & 0.609 & 0.780 & 0.789 & 0.759 & 0.732 & 0.677 & 0.802 & 0.751 & 0.925 & 0.762 \\
\hline SMI2 & 0.325 & 0.583 & 0.587 & 0.432 & 0.431 & 0.438 & 0.590 & 0.514 & 0.815 & 0.472 \\
\hline SMI3 & 0.592 & 0.786 & 0.797 & 0.715 & 0.707 & 0.689 & 0.785 & 0.733 & 0.918 & 0.724 \\
\hline TR1 & 0.913 & 0.662 & 0.665 & 0.885 & 0.878 & 0.792 & 0.701 & 0.641 & 0.575 & 0.841 \\
\hline TR2 & 0.659 & 0.852 & 0.869 & 0.870 & 0.827 & 0.662 & 0.886 & 0.914 & 0.698 & 0.919 \\
\hline TR3 & 0.613 & 0.800 & 0.810 & 0.748 & 0.712 & 0.635 & 0.913 & 0.797 & 0.724 & 0.895 \\
\hline
\end{tabular}

Table 6. Correlation matrix.

\begin{tabular}{ccccccccccc}
\hline & CPI & FOS & MSI & PL & PPI & PSI & PUA & SAT & SMI & TR \\
\hline CPI & 0.940 & & & & & & & & & \\
FOS & 0.668 & 0.884 & & & & & & & & \\
MSI & 0.671 & 0.839 & 0.900 & & & & & & & \\
PL & 0.895 & 0.835 & 0.845 & 0.902 & & & & & & \\
PPI & 0.888 & 0.808 & 0.818 & 0.981 & 0.879 & & & & & \\
PSI & 0.860 & 0.700 & 0.707 & 0.831 & 0.793 & 0.880 & & & & \\
PUA & 0.703 & 0.828 & 0.809 & 0.880 & 0.849 & 0.764 & 0.890 & & & \\
SAT & 0.640 & 0.840 & 0.854 & 0.850 & 0.815 & 0.677 & 0.809 & 0.892 & & \\
SMI & 0.594 & 0.819 & 0.829 & 0.739 & 0.724 & 0.695 & 0.830 & 0.766 & 0.887 & \\
TR & 0.811 & 0.877 & 0.828 & 0.939 & 0.806 & 0.780 & 0.846 & 0.794 & 0.755 & 0.885 \\
\hline
\end{tabular}

\subsection{Validation Inner Model and Hypotheses Results}

Inner model validation in PLS is used to test hypotheses using bootstrapping. For the hypothesis to be accepted, the $t$-value must be greater than 1.95 . Table 7 describes the results of hypothesis testing, path coefficients, $p$-values, and $t$-values. The results showed that of the 12 hypotheses there were 8 significant and positive values, while 4 hypotheses were declared insignificant. Figure 2 describes and illustrates the hypothetical results. 
Table 7. Results of the inner model result.

\begin{tabular}{|c|c|c|c|c|}
\hline Hypothesis & Path Hypothesis & Number of Path Coefficient & Results of $t$-Value & Results \\
\hline $\mathrm{H} 1$ & RQ -> PPI & 0.5184 & 3.7301 & Accepted \\
\hline $\mathrm{H} 2$ & RQ $\rightarrow$ PL & 0.9226 & 71.2221 & Accepted \\
\hline H3 & FOS $->$ PPI & -0.04 & 0.2358 & Rejected \\
\hline $\mathrm{H} 4$ & FOS -> RQ & -0.15 & 0.7916 & Rejected \\
\hline H5 & MSI $->$ PPI & -0.0513 & 0.264 & Rejected \\
\hline H6 & MSI -> RQ & 0.6383 & 3.2442 & Accepted \\
\hline H7 & $\mathrm{SMI}->\mathrm{RQ}$ & -0.1417 & 3.1773 & Accepted \\
\hline $\mathrm{H} 8$ & PUA -> RQ & 0.5552 & 6.9308 & Accepted \\
\hline H9 & PSI $->$ RQ & -0.0777 & 1.4995 & Rejected \\
\hline H10 & PSI -> PPI & 0.3283 & 4.8841 & Accepted \\
\hline H11 & CPI $\rightarrow$ PPI & 0.2774 & 4.9594 & Accepted \\
\hline $\mathrm{H} 12$ & CPI -> RQ & 0.184 & 3.6864 & Accepted \\
\hline
\end{tabular}

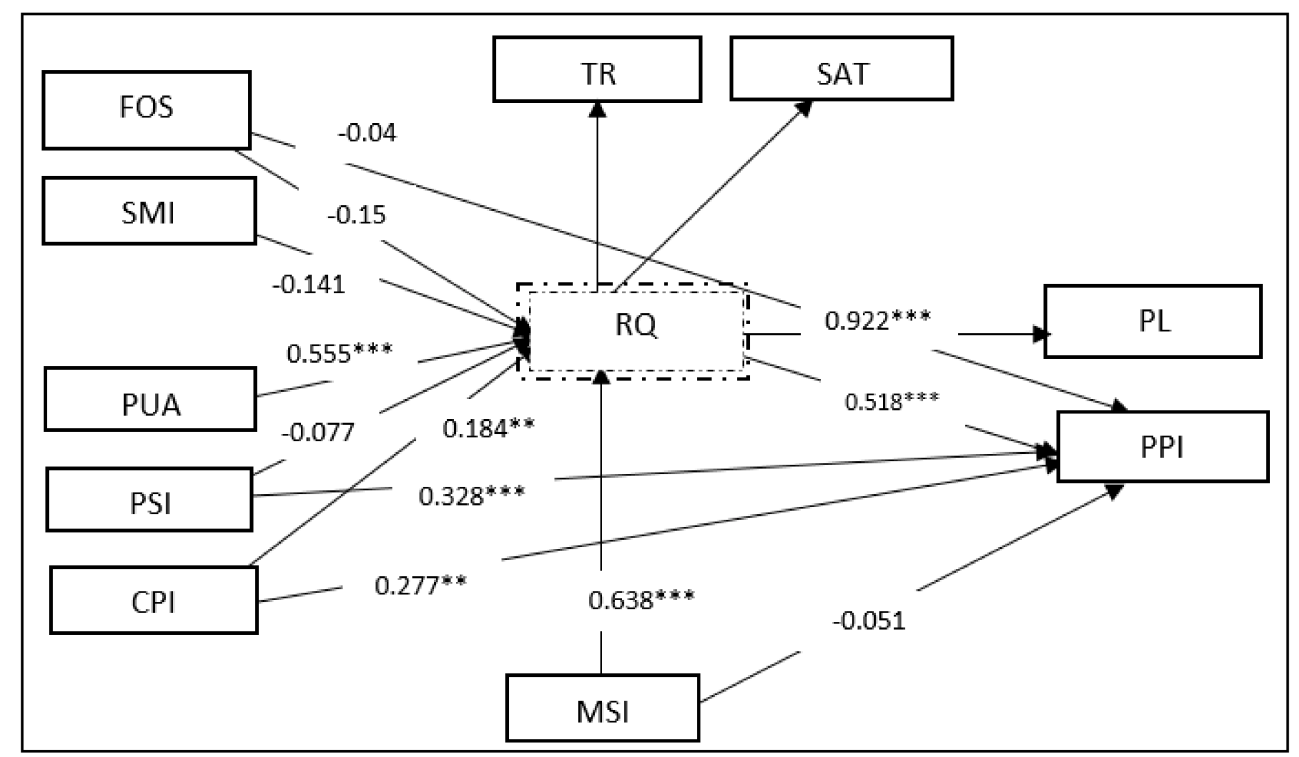

Figure 2. Path coefficients. ${ }^{* *} p$-value $<0.01 ;{ }^{* * *} p$-value $<0.001$.

Table 7 and Figure 2 show that $\mathrm{H} 1$ and $\mathrm{H} 2$ are both positive and both have a significant effect, RQ to PL (RQ-PL, $\beta=0.9226, t$-value $=71.2221$ ), and RQ against PPI (RQ-PPI, $\beta=0.5184, t$-value $=3.7301)$, then both are accepted.

In $\mathrm{H} 3$ and $\mathrm{H} 4$, it is said to be rejected, negative value and insignificant effect of FOS on PPI and also FOS on RQ.

In H5, where MSI is a negative value and insignificant effect of PPI (MSI-PPI, $\beta=-0.0513, t$-value $=0.264$ ), then, $\mathrm{H} 5$ is declared rejected.

Furthermore, H6 shows MSI to RQ is positive and has a strong significant effect (MSI-RQ, $\beta=0.6383, t$-value $=3.2442$ ), therefore, H6 is declared accepted.

Furthermore, H7 shows that SMI to RQ is positive and has a strong significant effect (SMI-RQ, $\beta=-0.1417$, $t$-value $=3.1773$ ), therefore, H7 is declared accepted.

Furthermore, in H8, the correlation between PUA and RQ is positive and has a strong significant effect (PUA-RQ, $\beta=0.5552, t$-value $=6.9308)$, then, $\mathrm{H} 8$ is declared accepted

In $\mathrm{H} 9$, it is rejected because it is negative and insignificant with a $t$-value below 1.95 .

However, it is the opposite, for PSI to PPI, in this study, it is positive and has a strong significant effect (PSI-PPI, $\beta=0.3283, t$-value $=4.8841$ ), therefore, $\mathrm{H} 10$ is appropriate .

CPI is positive and has a significant effect on PPI, therefore, H11 is accepted (CPI-PPI, $\beta=0.2774, t$-value $=4.9594)$. Then, $C P I$ against $R Q$ is positive and has a significant effect, then, $\mathrm{H} 12$ is accepted $(\mathrm{CPI}-\mathrm{RQ}, \beta=0.184, t$-value $=3.6864)$. 


\subsection{Testing of Mediation Effects}

To quantify the value of mediation effects in this study using the Sobel test, the analysis results are explained in $Z$ value. Table 8 explains that the value of $Z$ value is greater than 1.96 , so the mediation effect on each variable quantify is accepted and significant.

Table 8. Results of mediation test.

\begin{tabular}{cccc}
\hline Construct & Relationship Construct & Number of $\boldsymbol{t}$-Value & Number of Sobel Test's with z-Value \\
\hline SMI-RQ-PPI & SMI-RQ & 3.1773 & $2.4187^{*}$ \\
& RQ-PPI & 3.7301 & $3.1741^{* *}$ \\
SMI-RQ-PL & SMI-RQ & 3.1773 & $3.2846^{* *}$ \\
PUA-RQ-PPI & RQ-PL & 71.2221 & $6.8982^{* *}$ \\
PUA-RQ-PL & PUA-RQ & 6.9308 & $2.6219^{* *}$ \\
CPI-RQ-PPI & RQ-PPI & 3.7301 & $3.6814^{* * *}$ \\
& PUA-RQ & 6.9308 & $2.4478^{*}$ \\
CPI-RQ-PL & RQ-PL & 71.2221 & $3.2408^{* *}$ \\
MSI-RQ-PPI & RQ-PQ & 3.6864 & 3.7301 \\
MSI-RQ-PL & CPI-RQ & 3.6864 & 71.2221 \\
& RQ-PL & 3.2442 & 3.7301 \\
\hline
\end{tabular}

Note: ${ }^{*} p$-value $<0.01 ;{ }^{* *} p$-value $<0.001 ;{ }^{* * *} p$-value $<0.0001$.

\section{Discussion}

This study focused on a combination of the quality of current electronic government technology [5]. Then, the six variables of electronic government quality were combined with connection quality as a factor that influences both types of citizen behavior outcomes to examine electronic government as a citizen service. The high quality and good quality of electronic government affects the citizens' perspective and has an effect on the sustainability of electronic government facilities.

From the results of the analysis carried out in this study, there are several conclusions that can be drawn. RQ is a variable that supports the creation of PPI and PL, this has similarities with the views of previous researchers who stated that RQ is a determining factor for customer behavioral motives in activities. In social media commerce, Hariguna et al. [3] further confirmed that contentment and credence as RQ constructs are determinants of motive to use electronic government facilities. Furthermore, the connections among the variables MSI, SMI, and PUA have a positive and significant value on RQ; this is in line with several previous studies including $[3,5,6]$ which stated that these variables are part of the antecedent RQ. There are several significant findings and benefactions based on the empirical results of this study, both for academics and practitioners.

\subsection{Theoretical Implications}

This study contributes to the literature on the combination of electronic government quality into the six variable constructs set out and discussed in depth. First, we provide a holistic antecedent model for citizen behavioral outcomes (citizens' motives and citizens ${ }^{\prime}$ faithfulness) in terms of electronic government valuation content. Although the concept of electronic government facilities has been discussed in previous studies, the holistic model that explains citizen motives and citizen faithfulness in a platform is still very poorly discussed. Secondly, this is the first study to confirm the concept of electronic government quality of the latest technology and its combination with relationship quality. Although studies have widely acknowledge that several variables in electronic government quality are correlated and shape connection quality, this study also makes a significant contribution to the literature related to the new dataset of electronic government survey results. 


\subsection{Managerial Implications}

This study makes a special benefaction to electronic government providers to consider the use of e-participation, mobile government, social media, mobile facilities, current information, and fully online facilities as variables of electronic government quality. The results show the importance of integrating these variables to influence citizens' perspectives in the context of connection quality (citizens' contentment and citizens' credence).

On the basis of Hypotheses 1 and 2, the test results found that the quality of the connection has a significant influence on citizens' motives and citizens' faithfulness, therefore, for the government as electronic government managers must be able to ensure that every content contained in electronic government must provide information that is concrete, relevant and accurate. The contentment that people get after using electronic government will have a direct effect on faithfulness and sustainability in using electronic government facilities in the future. While the sense of security felt by society after using electronic government facilities is also a positive implication that has an effect on peoples' motives and faithfulness. Service providers in this case must be able to ensure that the electronic government system that has been built has met good and safe quality standards, and it must be ensured that the data and transactions running on the electronic government system are safe from cybercrime. Furthermore, the sense of security felt by society is an extension of society contentment.

From the test results, Hypotheses 3-5 and 9 were rejected. This proves that one of the supports for the effectiveness enforcement of electronic government is the maturity of society in using electronic government facilities. From Hypotheses 3 and 4 it can be seen that there are still many people who cannot yet accept if all electronic government activities use the full online service concept, therefore, the government must provide a dual scheme to overcome this problem. While Hypothesis 5 shows that mobile government does not directly have a significant effect on peoples' motives. This gives an illustration to the government that not all people are ready to use mobile government; many reasons include the ease of using applications for lack of credence in technology. In contrast to Hypothesis 6, mobile government has a good number and positive value and has a strong significant impact on the variable relationship quality, therefore, the presence of mobile government can bridge society's readiness for mobile technology. The presence of mobile service combination in electronic government is also growing. The citizen feels the merits of using mobile-based applications for electronic government facilities significantly affects the quality of the connection, as stated in Hypothesis 6. Mobile government service providers must maintain and even improve the quality of applications by maintaining citizen security and privacy, providing navigation and content convenience for mobile activities.

The high use of social media among society today has an effect on the combination of electronic government facilities with social media. This combination can provide chances for the citizen to interact with electronic government service providers. People can provide feedback about how they feel when using electronic government facilities because of Hypothesis 7.

In addition, personalized user accounts in this study have been shown to significantly affect the quality of connections. This proves that people tend to use electronic government for their needs. Therefore, there is a need for urgent and specific accounts to be implemented, as state in Hypothesis 8.

The discussion about the combination of e-participation facilities in this study is very interesting. We find that e-participation facilities do not significantly affect connection quality, as stated in Hypothesis 9, but have a significant effect on citizen motive, as stated in Hypothesis 10. Citizen awareness of electronic government facilities increases with citizen involvement. Communities are more likely to be able to engage actively with this technology combination. People tend to be lazy or indifferent to what they feel, but with e-participation, people can provide feedback directly by using their gadgets.

Hypotheses 11 and 12 show a significant effect between citizens' current information on the quality of connections and citizens' motives. Citizen concern for information is 
currently very high where people want to get information directly and accurately from credence sources. Therefore, information providers must ensure that the information provided to the citizen is the most contemporary information. Because, if the information cannot be accessed in a contemporary manner, there is a lot of information sourced by the citizen whose degree of information is still questionable or has hoax value.

\section{Conclusions and Future Work}

In the current digital era, the government as an electronic government provider is increasingly aware that electronic government variables and content must keep pace with technological changes. The citizen as users of electronic government facilities should be able to feel the merits of these facilities. Electronic government is present from the aspect of economic merits and also from electronic government as a transformation of government in serving the society more adaptively. Citizen interaction with the government can be done by integrating social media, while citizen participation can use the concept of e-participation. People need contemporary information so that it can be widely accessed, by utilizing the concept of mobile government, the citizen can more easily access the activities they need, because nowadays almost everyone can use a mobile phone. Therefore, the government as a service provider must understand and be aware of the current technological shift, which during the COVID-19 pandemic has mostly turned into a digital society.

All of these activities have an effect on the quality of relations between the citizen and government; managing the connection between the citizen and good governance is one of the strategies needed to achieve electronic government goals. Furthermore, the two behavioral concepts of citizen motive and citizen faithfulness have a good and positive value, and also have a strong impact on the quality of the connection.

This study adopts the latest technologies that we conceptualize into electronic government quality and is integrated with the concept of connection quality to quantify citizens' motives and citizens' faithfulness to electronic government facilities. Further studies related to this combination are needed, due to the lack of discussion regarding the two concepts. In addition, studies are needed that expand the scope of the distribution of respondents to obtain more relevant data and results. Furthermore, this study was conducted in Indonesia and may have significant differences if done in several different countries. Then, the integrated framework variables would allow for more varied additions, such as local wisdom within a country. Finally, very rapid technological changes can change the e-commerce pattern of government, such as blockchain technology.

Author Contributions: Conceptualization, T.H. and A.R.; methodology, T.H.; software, S.; validation, T.H., A.R. and S.; formal analysis, T.H.; investigation, T.H.; resources, A.R.; data curation, S.; writingoriginal draft preparation, T.H.; writing—-review and editing, A.R.; visualization, T.H.; supervision, A.R.; project administration, S.; funding acquisition, A.R. All authors have read and agreed to the published version of the manuscript.

Funding: This research received no external funding.

Institutional Review Board Statement: Ethical review and approval was not required for this study on human participants in accordance with the local legislation and institutional requirements.

Informed Consent Statement: Written informed consent from the patients/participants was not required to participate in this study in accordance with the national legislation and the institutional requirements.

Data Availability Statement: The raw data supporting the conclusions of this article will be made available by the authors, without undue reservation, to any qualified researchers.

Conflicts of Interest: The authors declare no conflict of interest. 


\section{References}

1. Herrando, C.; Jiménez-Martínez, J.; de Hoyos, M.J.M. Boosting Purchase Intention and Online Participation through Passion. Int. J. Inform. Inf. Syst. 2020, 3, 136-145.

2. Hariguna, T.; Tsamara, M. E-Government Asset Management Using the Extreme Programming Method. Int. J. Inform. Inf. Syst. 2019, 2, 24-32. [CrossRef]

3. Hariguna, T.; Rahardja, U.; Ruangkanjanases, A. The impact of citizen perceived value on their intention to use e-government services: An empirical study. Electron. Gov. 2020, 16, 426-440. [CrossRef]

4. Abbas, S.A. Entrepreneurship and Information Technology Businesses in Economic Crisis. Entrep. Sustain. Issues 2018, 5, 682-692. [CrossRef]

5. Wirtz, B.W.; Kurtz, O.T. Local E-Government and User Satisfaction with City Portals-The citizens'service preference perspective. Int. Rev. Public Nonprofit Mark. 2016, 13, 265-287. [CrossRef]

6. Wirtz, B.W.; Piehler, R. eGovernment applications and public personnel acceptance: An empirical analysis of the public servant perspective. Int. J. Public Adm. 2016, 39, 238-247. [CrossRef]

7. Aziz, A.; Zaki, R.; Ullah, S.E. The Impact of Dynamic Capabilities and Information System on Organizational Effectiveness in Cellular Communication Companies in Jordon: Mediating Role of Organizational Ambidexterity. Int. J. Inform. Inf. Syst. 2020, 3, 81-93. [CrossRef]

8. Wibowo, A.; Chen, S.-C.; Wiangin, U.; Ma, Y.; Ruangkanjanases, A. Customer Behavior as an Outcome of Social Media Marketing: The Role of Social Media Marketing Activity and Customer Experience. Sustainability 2021, 13, 189. [CrossRef]

9. Chen, S.-C.; Jong, D.; Lai, M.-T. Assessing the Relationship between Technology Readiness and Continuance Intention in an E-Appointment System: Relationship Quality as a Mediator. J. Med. Syst. 2014, 38, 76. [CrossRef] [PubMed]

10. Kaisara, G.; Pather, S. The e-Government evaluation challenge: A South African batho Pele-aligned service quality approach. Gov. Inf. Q. 2011, 28, 211-221. [CrossRef]

11. Ozkan, S.; Kanat, I.E. e-Government adoption model based on theory of planned behavior: Empirical validation. Gov. Inf. $Q$. 2011, 28, 503-513. [CrossRef]

12. Rana, N.P.; Williams, M.D.; Dwivedi, Y.K. Diversity and diffusion of therories, models, and theoretical constructs in eGovernment research. Electron. Gov. 2011, 6846, 1-12.

13. Sagiyeva, R.; Zhuparova, A.; Ruzanov, R.; Doszhan, R.; Askerov, A. Intellectual input of development by knowledge-based economy: Problems of measuring in countries with developing markets. Entrep. Sustain. Issues 2018, 6, 711-728. [CrossRef]

14. Tvaronavičienè, M.; Plèta, T.; Della Casa, S.; Latvys, J. Cyber security management of critical energy infrastructure in national cybersecurity strategies: Cases of USA, UK, France, Estonia and Lithuania. Insights Reg. Dev. 2020, 2, 802-813. [CrossRef]

15. Chen, Y.; Huang, T.; Hung, S. The Charisma of Online Group-Buying: The Moderating Role of Social Motivation. Int. J. Inform. Inf. Syst. 2019, 2, 99-101.

16. Glotko, A.V.; Polyakova, A.G.; Kuznetsova, M.Y.; Kovalenko, K.E.; Shichiyakh, R.A.; Melnik, M.V. Main trends of government regulation of sectoral digitalization. Entrep. Sustain. Issues 2020, 7, 2181-2195. [CrossRef]

17. Chrzaścik, M. Modelling promotion strategies in local government units with the application of structural equation modelling (SEM) with an example of Warmia and Mazury region. Entrep. Sustain. Issues 2019, 7, 1258-1278. [CrossRef]

18. Crosby, L.A.; Evans, K.R.; Cowles, D. Relationship Quality in Services Selling: An Interpersonal Influence Perspective. J. Mark. 1990, 54, 68-81. [CrossRef]

19. Palmatier, R.W.; Dant, R.P.; Grewal, D.; Evans, K.R. Factors influencing the effectiveness of relationship marketing: A metaanalysis. J. Mark. 2006, 70, 136-153. [CrossRef]

20. Tajvidi, M.; Richard, M.-O.; Wang, Y.; Hajli, N. Brand co-creation through social commerce information sharing: The role of social media. J. Bus. Res. 2018, 121, 1-11. [CrossRef]

21. Anastasiei, B.; Dospinescu, N. Facebook Advertising, Relationship between Types of Message, Brand Attitude and Perceived Buying Risk. Ann. Econ. Ser. 2017, 6, 18-26.

22. Bejou, D.; Wray, B.; Ingram, T.N. Determinants of relationship quality: An artificial neural network analysis. J. Bus. Res. 1996, 36, 137-143. [CrossRef]

23. Giovanis, A.; Athanasopoulou, P.; Tsoukatos, E. The role of service fairness in the service quality—Relationship quality-Customer loyalty chain: An empirical study. J. Serv. Theory Pract. 2015, 25, 744-776. [CrossRef]

24. Chen, C.-C.; Chang, Y.-C. What drives purchase intention on Airbnb? Perspectives of consumer reviews, information quality, and media richness. Telemat. Inform. 2018, 35, 1512-1523. [CrossRef]

25. Oliveira, T.; Alhinho, M.; Rita, P.; Dhillon, G. Modelling and testing consumer trust dimensions in e-commerce. Comput. Hum. Behav. 2017, 71, 153-164. [CrossRef]

26. Hajli, M.N. The role of social support on relationship quality and social commerce. Technol. Forecast. Soc. Chang. 2014, 87, 17-27. [CrossRef]

27. Garbarino, E.; Johnson, M.S. The different roles of satisfaction, trust, and commitment in customer relationships. J. Mark. 1999, 63, 70-87. [CrossRef]

28. Rajaobelina, L.; Bergeron, J. Antecedents and consequences of buyer-seller relationship quality in the financial services industry. Int. J. Bank Mark. 2009, 27, 359-380. [CrossRef] 
29. Hsu, C.-L.; Chen, M.-C.; Kikuchi, K.; Machida, I. Elucidating the determinants of purchase intention toward social shopping sites: A comparative study of Taiwan and Japan. Telemat. Inform. 2017, 34, 326-338. [CrossRef]

30. Chen, S.-C.; Liu, S.-C.; Li, S.-H.; Yen, D.C. Understanding the mediating effects of relationship quality on technology acceptance: An empirical study of E-appointment system. J. Med. Syst. 2013, 37, 9981. [CrossRef]

31. Kim, W.G.; Lee, Y.-K.; Yoo, Y.-J. Predictors of Relationship Quality and Relationship Outcomes in Luxury Restaurants. J. Hosp. Tour. Res. 2006, 30, 143-169. [CrossRef]

32. Liu, C.-T.; Guo, Y.M.; Lee, C.-H. The effects of relationship quality and switching barriers on customer loyalty. Int. J. Inf. Manag. 2011, 31, 71-79. [CrossRef]

33. Boles, J.S.; Johnson, J.T.; Barksdale, H.C. How Salespeople Build Quality Relationships: A Replication and Extension. J. Bus. Res. 2000, 48, 75-81. [CrossRef]

34. Jap, S.D.; Manolis, C.; Weitz, B.A. Relationship Quality and Buyer-Seller Interactions in Channels of Distribution. J. Bus. Res. 1999, 46, 303-313. [CrossRef]

35. Holmlund, M. A definition, model, and empirical analysis of business-to-business relationship quality. Int. J. Serv. Ind. Manag. 2008, 19, 32-62. [CrossRef]

36. Pérez-Morote, R.; Pontones-Rosa, C.; Núñez-Chicharro, M. The effects of e-government evaluation, trust and the digital divide in the levels of e-government use in European countries. Technol. Forecast. Soc. Chang. 2020, 154, 11997. [CrossRef]

37. Khan, S.; Umer, R.; Umer, S.; Naqvi, S. Antecedents of trust in using social media for E-government services: An empirical study in Pakistan. Technol. Soc. 2021, 64, 101400. [CrossRef]

38. Masri, N.W.; You, J.-J.; Ruangkanjanases, A.; Chen, S.-C.; Pan, C.-I. Assessing the effects of information system quality and relationship quality on continuance intention in e-tourism. Int. J. Environ. Res. Public Health 2020, 17, 174. [CrossRef]

39. Tsai, H.-T.; Huang, H.-C. Determinants of e-repurchase intentions: An integrative model of quadruple retention drivers. Inf. Manag. 2007, 44, 231-239. [CrossRef]

40. Meyer, C. Reinforcing Comparative Monitoring of Smart Specialisation Performance across European Regions: Transnational RIS3 Observatory Model as a Tool for Smart Specialisation Governance. Entrep. Sustain. Issues 2020, 8, 1386-1400. [CrossRef]

41. Aymagambetov, Y.; Grazhevskaya, N.; Tyngisheva, A. Estimation the effectiveness of public governance of the health system in the context of sustainable development. Entrep. Sustain. Issues 2020, 7, 3309-3320. [CrossRef]

42. Schiffman, L.G.; Kanuk, L.L. Consumer Behavior, 10th ed.; Prentice Hall: Upper Saddle River, NJ, USA, 2009.

43. Hee, Y.K.; Jae-Eun, C. Consumer purchase intention for organic personal care products. J. Consum. Mark. 2011, $28,40-47$.

44. Lu, Y.; Zhao, L.; Wang, B. From virtual community members to C2C e-commerce buyers: Trust in virtual communities and its effect on consumers' purchase intention. Electron. Commer. Res. Appl. 2010, 9, 346-360. [CrossRef]

45. Adamczyk, M.; Betlej, A.; Gondek, J.; Ohotina, A. Technology and sustainable development: Towards the future? Entrep. Sustain. Issues 2019, 6, 2003-2016. [CrossRef]

46. Sen Doong, H.; Wang, H.C.; Foxall, G.R. Psychological traits and loyalty intentions towards e-Government services. Int. J. Inf. Manag. 2010, 30, 457-464. [CrossRef]

47. Wang, C.; Teo, T.S.H.; Liu, L. Perceived value and continuance intention in mobile government service in China. Telemat. Inform. 2020, 48, 101348. [CrossRef]

48. Alarabiat, A.; Soares, D.; Estevez, E. Determinants of citizens' intention to engage in government-led electronic participation initiatives through Facebook. Gov. Inf. Q. 2021, 38, 101537. [CrossRef]

49. Flavián, C.; Guinalíu, M.; Gurrea, R. The role played by perceived usability, satisfaction and consumer trust on website loyalty. Inf. Manag. 2006, 43, 1-14. [CrossRef]

50. Shevyakova, A.; Munsh, E.; Arystan, M.; Petrenko, Y. Competence development for Industry 4.0: Qualification requirements and solutions. Insights Reg. Dev. 2021, 3, 124-135.

51. Chehabeddine, M.; Tvaronavičienè, M. Securing regional development. Insights Reg. Dev. 2020, 2, 430-442. [CrossRef]

52. Hapsari, R.; Clemes, M.D.; Dean, D. The impact of service quality, customer engagement and selected marketing constructs on airline passenger loyalty. Int. J. Qual. Serv. Sci. 2017, 9, 21-40. [CrossRef]

53. Algesheimer, R.; Dholakia, U.M.; Herrmann, A. The Social Influence of Brand Community: Evidence from European Car Clubs. J. Mark. 2005, 69, 19-34. [CrossRef]

54. Chen, S.-C.; Lin, C.-P. Understanding the effect of social media marketing activities: The mediation of social identification, perceived value, and satisfaction. Technol. Forecast. Soc. Chang. 2019, 140, 22-32. [CrossRef]

55. Dodds, W.B.; Monroe, K.B.; Grewal, D. Effects of Price, Brand, and Store Information on Buyers' Product Evaluations. J. Mark. Res. 1991, 28, 307-319.

56. Bonsón, E.; Carvajal-Trujillo, E.; Escobar-Rodríguez, T. Escobar-Rodríguez, Influence of trust and perceived value on the intention to purchase travel online: Integrating the effects of assurance on trust antecedents. Tour. Manag. 2015, 47, 286-302. [CrossRef]

57. Zhang, K.Z.; Benyoucef, M.; Zhao, S.J. Building brand loyalty in social commerce: The case of brand microblogs. Electron. Commer. Res. Appl. 2016, 15, 14-25. [CrossRef]

58. Assar, S.; Boughzala, I.; Boydens, I. Practical studies in e-Government: Best Practices from around the World; Springer: New York, NY, USA, 2011.

59. Bonsón, E.; Royo, S.; Ratkai, M. Citizens' Engagement on Local Governments' Facebook sites. An empirical analysis: The Impact of Different Media and Content Types in Western Europe. Gov. Inf. Q. 2015, 32, 52-62. [CrossRef] 
60. Al-Hujran, O. Toward the Utilization of m-Government Services in Developing Countries: A Qualitative Investigation. Int. J. Bus. Soc. Sci. 2012, 3, 155-160.

61. Zamzami, I.; Mahmud, M. Mobile interface for m-Government services: A framework for information quality evaluation. Int. J. Sci. Eng. Res. 2012, 3, 1-5.

62. Thongpapanl, N.; Rehman, A.A. Enhancing Online Performance through Website Content and Personalization. J. Comput. Inf. Syst. 2011, 52, 3-13.

63. Liao, S.S.; Li, Q.; Xu, D.J. A Bayesian Network-based Framework for Personalization in Mobile Commerce Applications. Commun. Assoc. Inf. Syst. 2005, 15, 494-511. [CrossRef]

64. Zheng, Y.; Schachter, H.L.; Holzer, M. The Impact of Government form on E-Participation: A Study of New Jersey Municipalities. Gov. Inf. Q. 2014, 31, 653-659. [CrossRef]

65. Themistocleous, M.; Azab, N.A.; Kamal, M.M.; Ali, M.; Morabito, V. Location-based Services for Public Policy Making: The Direct and Indirect Way to E-Participation. Inf. Syst. Manag. 2012, 29, 269-283. [CrossRef]

66. Lee, Y.; Kozar, K.A. Investigating the Effect of Website Quality on E-Business Success: An Analytic Hierarchy Process (AHP) Approach. Decis. Support Syst. 2006, 42, 1383-1401. [CrossRef]

67. Smith, A.G. Applying Evaluation Criteria to New Zealand Government Websites. Int. J. Inf. Manag. 2001, 21, 137-149. [CrossRef]

68. Dragulanescu, N.-G. On the Definition and Evaluation of Web Sites Quality. Stud. Infrom. Control 2001, 10. Available online: https://www.researchgate.net/publication/340778659_On_the_Definition_and_Evaluation_of_Web_Sites_Quality (accessed on 2 July 2021).

69. Lakeworth, S. How Important Is Branding to Your Marketing Strategy; ASYSS: Boston, MA, USA, 2008; Available online: https: / / proceedings.informingscience.org/InSITE2010/InSITE10p001-007Erkollar694.pdf (accessed on 8 January 2021).

70. Lu, B.; Fan, W.; Zhou, M. Social Presence, Trust, and Social Commerce Purchase Intention: An Empirical Research. Comput. Hum. Behav. 2016, 56, 225-237. [CrossRef]

71. Ali, F. Hotel Website Quality, Perceived Flow, Customer Satisfaction and Purchase Intention. J. Hosp. Tour. Technol. 2016, 7, 213-228. [CrossRef]

72. Hsu, C.-L.; Lin, J.C.-C. What Drives Purchase Intention for Paid Mobile Apps?-An Expectation Confirmation Model with Perceived Value. Electron. Commer. Res. Appl. 2015, 14, 46-57. [CrossRef]

73. Choi, Y.G.; Hyun, S.S. Relationships between Brand Experiences, Personality Traits, Prestige, Relationship Quality, and Loyalty: An Empirical Analysis of Coffeehouse Brands Analysis of Coffeehouse Brands 1185. Int. J. Contemp. Hosp. Manag. 2017, 29, 1185-1202. [CrossRef]

74. Linden, N.V.-D.; Schindler, R.; Aguzzi, S.; Jacquet, L.; Millard, J. Public Services Online. Digital by Default or by Detour? Assessing User Centric eGovernment Performance in Europe-e-Government Benchmark 2012; Insight Report: Luxembourg, 2013.

75. Al-Sebie, M. Organizational Challenges Facing Integrating E-Government Systems: An Empirical Study. Eur. Sci. J. 2014, 10, 236-250.

76. Al Thunibat, A.; Mat Zin, N.A.; Sahari, N. Mobile Government User Requirements Model. J. E Gov. 2011, 34, 104-111. [CrossRef]

77. Shareef, M.A.; Archer, N.; Dwivedi, Y.K. Examining Adoption Behavior of Mobile Government. J. Comput. Inf. Syst. 2012, $53,39-49$.

78. Lee, G.; Kwak, Y.H. An Open Government Maturity Model for Social Media-Based Public Engagement. Gov. Inf. Q. 2012, 29, 492-503. [CrossRef]

79. Bryer, T.A. The Costs of Democratization-Social Media Adaptation Challenges within Government Agencies. Adm. Theory Prax. 2011, 33, 341-361.

80. Morgeson, F.V.; Van Amburg, D.; Mithas, S. Misplaced Trust? Exploring the Structure of the EGovernment-Citizen Trust Relationship. J. Public Adm. Res. Theory 2011, 21, 257-283. [CrossRef]

81. Lee, D.-J.; Ahn, J.-H.; Bang, Y. Managing Consumer Privacy Concerns in Personalization: A Strategic Analysis of Privacy Protection. MIS Q. 2011, 35, 423-444. [CrossRef]

82. Sheng, H.; Nah, F.F.-H.; Siau, K. An Experimental Study on Ubiquitous Commerce Adoption: Impact of Personalization and Privacy Concerns. J. Assoc. Inf. Syst. 2008, 9, 344-376. [CrossRef]

83. Gulati, G.J.; Williams, C.B.; Yates, D.J. Predictors of Online Services and E-Participation: A Crossnational Comparison. Gov. Inf. Q. 2014, 31, 526-533. [CrossRef]

84. Roman, A.V.; Miller, H.T. New Questions for E-Government: Efficiency But Not (Yet?) Democracy. Int. J. Electron. Gov. Res. 2013, 9, 65-81. [CrossRef]

85. Wirtz, B.W.; Daiser, P. E-Government. Strategy Process Instruments; German University of Administrative Sciences Speyer: Speyer, Germany, 2015.

86. Kim, S.; Lee, J. E-Participation, Transparency, and Trust in Local Government. Public Adm. Rev. 2012, 72, 819-828.

87. Feeney, M.K.; Welch, E.W. Electronic Participation Technologies and Perceived Outcomes for Local Government Managers. Public Manag. Rev. 2012, 14, 815-833. [CrossRef]

88. King, W.R.; Epstein, B.J. Assessing Value of Information. Manag. Datamat. 1976, 5, 171-180.

89. Churchill, G.A.; Peter, J.P. Research Design Effects on the Reliability of Rating Scales: A Meta-Analysis. J. Mark. Res. 1984, 21, 360. [CrossRef] 
90. Anderson, J.C.; Gerbing, D.W. Structural Equation Modeling in Practice: A Review and Recommended Two-Step Approach. Psychol. Bull. 1988, 103, 411-423. [CrossRef]

91. Petter, S.; Straub, D.; Rai, A. Specifying Formative Constructs in Information Systems Research. MIS Q. 2007, 31, 623-656. [CrossRef]

92. Chin, W.W.; Newsted, P.R. Structural Equation Modeling Analysis with Small Samples Using Partial Least Squares. Stat. Strategy Small Sample Res. 1999, 1, 307-341.

93. Urbach, N.; Ahlemann, F. Structural Equation Modeling in Information Systems Research Using Partial Least Squares. J. Inf. Technol. Theory Appl. 2010, 11, 5-40.

94. Hair, J.F.; Ringle, C.M.; Sarstedt, M. PLS-SEM: Indeed a silver bullet. J. Mark. Theory Practice 2011, 19, 139-152. [CrossRef]

95. Fornell, C.; Larcker, D.F. Evaluating Structural Equation Models with Unobservable Variables and Measurement Error. J. Mark. Res. 1981, 18, 39-50. [CrossRef]

96. Hair, J.F., Jr.; Hult, G.T.M.; Ringle, C.; Sarstedt, M. A Primer on Partial Least Squares Structural Equation Modeling (PLS-SEM); Sage: Los Angeles, CA, USA, 2016. 